\title{
Effects of Kolaviron, the Major Constituent of Garcinia kola, on the Histology of the Hypothalamus, Pituitary, and Testes Using Adult Male Wistor Rats as a Model Organism
}

\author{
A. U. Obi ${ }^{1,2 *}$, P. U. Nwoha ${ }^{1}$ \\ ${ }^{1}$ Department of Anatomy and Cell Biology, Obafemi Awolowo University, Ile-Ife, Nigeria \\ ${ }^{2}$ Department of Anatomy and Neurobiology, Imo State University, Owerri, Nigeria \\ Email: ${ }^{*}$ austinhealth@yahoo.com
}

Received 31 October 2013; revised 10 December 2013; accepted 18 March 2014

Copyright (C) 2014 by authors and Scientific Research Publishing Inc.

This work is licensed under the Creative Commons Attribution International License (CC BY). http://creativecommons.org/licenses/by/4.0/

\section{(c) (i) Open Access}

\section{Abstract}

This study determined the effects of kolaviron on the histology of organs of the hypothalamic-pituitary-gonadal axis, mainly the hypothalamus, pituitary and testis. The aim was to ascertain if its consumption has deleterious effects on these organs. Thirty six adult Wistar rats divided into six groups of six animals each were used and kolaviron administered at 100, 200, 400 and $800 \mathrm{mg} / \mathrm{kg}$ body weight. The results showed that gross cellular depletion and desquamation of cells of testis significantly reduced number of cells in the hypothalamus and pituitary $(P<0.05)$. It significantly reduced the relative brain weight $(P<0.05)$. These findings suggest that kolaviron can alter the histology of the axis which may impair its reproductive function.

\section{Keywords}

Histology, Hypothalamus, Pituitary, Testis

\section{Introduction}

Kolaviron is the major constituent of Garcina kola. The extract is one of the numerous plant products, and nutritional supplements that have been found to have a wide range of medicinal value. It is a drug of plant origin, which has numerous biochemical importances in the human body system. It is a defatted ethanol extract as well as a bioflavonoid of plant origin [1]. Documented the ability of kolaviron to inhibit hydroxy and superoxide

${ }^{*}$ Corresponding author.

How to cite this paper: Obi, A.U. and Nwoha, P.U. (2014) Effects of Kolaviron, the Major Constituent of Garcinia Kola, on the Histology of the Hypothalamus, Pituitary, and Testes Using Adult Male Wistar Rats as a Model Organism. Forensic Medicine and Anatomy Research, 2, 80-87. http://dx.doi.org/10.4236/fmar.2014.23014 
anion radicals, which are known to play important role in the process of lipid peroxidation. Its anti-oxidant action on lipoprotein has been reported [2]. Kolaviron has been found to significantly prevent hepatotoxicity mediated by galactosamine, amanita toxin and paracetomol [3]. It has a profound effect on the hormone, erythropoietin in the kidney [4] [5]. It is reported that kolaviron causes impotency in male subjects, which has made Garcinia kola an unwelcomed substance in some cases, especially where the man is battling with child bearing. Yet [1] have shown that kolaviron could be used in the treatment of male infertility problems associated with oxidative stress damage.

These suggest that it could have effect on the hormones of the hypothalamic-pituitary-gonadal axis. Considering the usefulness of kolaviron, it becomes necessary to determine its effects on the morphology of the organs, particularly the organs of hypothalamic-pituitary-gonadal axis-hypothalamus, pituitary and testis.

\section{Materials and Methods}

Thirty six adult male Wistar rats weighing $180 \mathrm{~g}$ - $200 \mathrm{~g}$, aged 20 - 24 weeks, were used for this study. The animals were obtained from the Animal Holdings of the Department of Anatomy and Cell Biology, Obafemi Awolowo University, Ile-Ife. The animals were fed with standard rat pellet and given water liberally. They were randomly assigned to six groups A, B, C, D, E, and F, of six rats each. Animals were housed in clean plastic cages under natural light and dark cycle, and at room temperature. Animals in group A served as primary control, those in group B served as secondary control. The animals in groups C, D, E, F, formed the experimental groups. All animals were handled with care in accordance with guidelines for animal research as detailed in the NIH guidelines for the care and use of laboratory Animal (NIH publication, 1985).

Kolaviron was extraced by the procedure of Farombi [6]. Briefly, Garcinia kola nuts were purchased from local market in Ile-Ife, Nigeria. The seeds were peeled and air dried in the laboratory. Air dried seeds were ground into powdered form. The powdered seeds were extracted with n-hexane, in a soxhlet extractor. The de- fatted, dried mass was repacked and then extracted with methanol in a soxhlet extractor. The extract was con- centrated and diluted to twice its volume in distilled water and partitioned with chloroform. The concentrated chloroform fraction gave a yellow-brown solid known as kolaviron, which was allowed to dry in oven $\left(40^{\circ} \mathrm{C}\right)$, and ground to powdered form.

Kolaviron was administered at 100, 200, 400 and $800 \mathrm{mg} / \mathrm{kg}$ body weight to each of the animals in groups C, $\mathrm{D}, \mathrm{E}$, and F respectively. Animals in group B were administered corn oil, while those in group A (control) received normal saline [7]. All administration was by gastric intubation which lasted for eight weeks. The coin oil was obtained from Sigma Chemical, USA.

At the end of administration of Kolaviron (experiment), the animals were sacrificed by cervical dislocation; the hypothalamus, pituitary and testes were dissected out and fixed in $10 \%$ formal saline for histological studies. Haematoxylin and Eosin method Drury and Wallington, [8] was used to show the histology and morphology of the organs of the treated and control groups. Relative weight of brain, and testis were calculated.

Slides were viewed under a Leica DM750 microscope and digital photomicrographs taken by an attached Leica ICC50 camera. Photomicrographs of haematoxylin and eosin stained sections were imported on to OpenOffice.org ${ }^{\mathrm{TM}}$ (OOo-dev 3.4.0) software for histomorphometric analysis. One-way ANOVA was used to analyze data followed by Student Newman-Keuls (SNK) test for multiple comparisons. Primer for windows (McGraw-Hill, version 4.0.0.0) was the statistical package used to analyze data. Results were expressed as mean \pm standard error of mean. $\mathrm{P}<0.05$ was set as accepted level of significant difference.

\section{Results}

\subsection{Physical Observation}

Animals in group F that were given $800 \mathrm{mg} / \mathrm{kg}$ body weight of kolaviron had increase in bolls of urine and watery stool, and these made the cage to be always wet. They also exhibited loss of body hair, and grooming was high. Macroscopic observation of the testes showed transparent covering from the outer layer in which the blood vessels were exposed with purplish colouration to the inner layer. For group E, administered $400 \mathrm{mg} / \mathrm{kg}$ body weight of kolaviron there was also increase in bolls of urine, and watery stool, like those of group F. For groups C, D, and primary and secondary controls, A and B, there was no apparent loss of body hair, and grooming was less apparent. The difference in mean body weight shown in Table 1 indicates that groups B, D, E and F had 
significantly reduced body weight gain when compared to group A (control group); and also that group E was significantly lower when compared to group $\mathrm{C}(\mathrm{P}<0.05)$. Generally, there was weight gain in all groups of animals except for group $\mathrm{E}$ that showed slight lost in body weight. Table 2 shows relative brain, and testis weights. It indicates that there was no significant difference in relative brain weight (RBW) and testis weight in all the groups $(\mathrm{P}>0.05)$. In group $\mathrm{F}$ that relative brain weight was significantly lower compared to controls $\mathrm{A}$, and $\mathrm{B}$, and experimental groups $\mathrm{C}, \mathrm{D}$, and $\mathrm{E}(\mathrm{P}<0.05)$.

The Table 3 shows mean values of cells counted for the hypothalamus, and pituitary. Neurons of hypothalamus in the secondary control group, 100, 200 and $400 \mathrm{mg} / \mathrm{kg}$ body weight of kolaviron groups were significantly lower than in the primary control group $(\mathrm{P}<0.05)$. The neurons of hypothalamus in 100, 400 and $800 \mathrm{mg} / \mathrm{kg}$ body weight kolaviron were significantly higher than the secondary control group ( $\mathrm{P}>0.05$ ), while the 200 $\mathrm{mg} / \mathrm{kg}$ body weight was significantly lower than the secondary control group $(\mathrm{P}<0.05)$. The 200 and $400 \mathrm{mg} / \mathrm{kg}$ body weight groups were significantly lower in neurons than the $100 \mathrm{mg} / \mathrm{kg}$ body weight group $(\mathrm{P}<0.05)$, and $800 \mathrm{mg} / \mathrm{kg}$ showed significantly high value than the $100 \mathrm{mg} / \mathrm{kg}$ body weight of kolaviron (P > 0.05). 400 and $800 \mathrm{mg} / \mathrm{kg}$ body weight of kolaviron showed significantly high value than in the $200 \mathrm{mg} / \mathrm{kg}$ body weight group

Table 1. Body weight change between the initial and final administration of kolaviron in rats.

\begin{tabular}{cccc}
\hline Group & Initial Body Weight $(\mathrm{g})$ & Final Body Weight $(\mathrm{g})$ & Body Weight Gain/Loss $(\mathrm{g})$ \\
\hline Group A & $156.7 \pm 6.41$ & $171.7 \pm 7.71$ & $15 \pm 2.58$ \\
Group B & $152.5 \pm 4.79$ & $153.3 \pm 3.80$ & $0.83 \pm 3.01^{*}$ \\
Group C & $155.8 \pm 1.537$ & $164.2 \pm 4.55$ & $8.33 \pm 3.58$ \\
Group D & $175.8 \pm 3.01$ & $178.3 \pm 2.47$ & $2.5 \pm 2.14^{*}$ \\
Group E & $177.5 \pm 3.10$ & $174.2 \pm 10.68$ & $-3.33 \pm 2.47^{*} \delta$ \\
Group F & $200 \pm 1.83$ & $201.7 \pm 5.11$ & $1.68 \pm 3.33^{*}$ \\
\hline
\end{tabular}

Values are mean \pm Standard Error of Mean (SEM) of data from the animals. " Implies significant difference when compared to Group A; ${ }^{\delta}$ Implies significant difference between Groups C and E. Significance was verified with ANOVA. Student Newman-Keuls (SNK) test was used for multiple comparisons. $\mathrm{P}<0.05 ; \mathrm{N}=6$.

Table 2. Relative organ weight of kolaviron treated rats.

\begin{tabular}{cccc}
\hline Group & Brain Weight $(\mathrm{g})$ & Right Testis Weight $(\mathrm{g})$ & Left Testis Weight (g) \\
\hline Group A & $1.25 \pm 0.08$ & $0.40 \pm 0.08$ & $0.41 \pm 0.07$ \\
Group B & $1.38 \pm 0.04$ & $0.53 \pm 0.13$ & $0.50 \pm 0.13$ \\
Group C & $1.30 \pm 0.03$ & $0.56 \pm 0.08$ & $0.55 \pm 0.08$ \\
Group D & $1.17 \pm 0.02 \S$ & $0.68 \pm 0.04$ & $0.67 \pm 0.03$ \\
Group E & $1.26 \pm 0.03$ & $0.57 \pm 0.08$ & $0.59 \pm 0.10$ \\
Group F & $1.04 \pm 0.04^{* \delta \delta \lambda}$ & $0.69 \pm 0.01$ & $0.68 \pm 0.01$ \\
\hline
\end{tabular}

Values are mean \pm Standard Error of Mean (SEM) of data from the animals. " Implies significant difference when compared to Group A. ${ }^{\S}$ Implies significant difference compared with Group B; ${ }^{\delta}$ Implies significant difference between Groups C and F; ${ }^{\lambda}$ Implies significant difference between Groups E and F. Significance was verified with ANOVA. SNK test was used for multiple comparisons. $\mathrm{P}<0.05 ; \mathrm{N}=6$.

Table 3. Cell counting.

\begin{tabular}{cccccc}
\hline \multirow{2}{*}{ Groups } & \multicolumn{3}{c}{ Hypothalamus $\left(/ 10^{3} \mu \mathrm{m}^{2}\right)$} & \multicolumn{2}{c}{ Pituitary $\left(/ 10^{3} \mu \mathrm{m}^{2}\right)$} \\
\cline { 2 - 5 } & Neurons & Granule Cells & Neuronal Fibres & Acidophils & Basophils \\
\hline Group A & $364 \pm 0.58$ & $103.7 \pm 0.88$ & $30 \pm 0.59$ & $631 \pm 1.52$ & $185 \pm 0.57$ \\
Group B & $238.3 \pm 0.88^{*}$ & $156.3 \pm 0.89^{*}$ & $75 \pm 0.57^{*}$ & $481 \pm 0.32^{*}$ & $199.3 \pm 1.20^{*}$ \\
Group C & $332.3 \pm 0.66^{* \S}$ & $179 \pm 0.57^{* \S}$ & $37.33 \pm 0.88^{* \S}$ & $474 \pm 0.57^{* \S}$ & $205 \pm 0.57^{* \S}$ \\
Group D & $214 \pm 0.58^{* \S \delta}$ & $141.7 \pm 1.20^{* \S \delta}$ & $81.67 \pm 1.20^{* \S \delta}$ & $245.7 \pm 1.20^{* \S \delta}$ & $272.7 \pm 0.89^{* \S \delta}$ \\
Group E & $282 \pm 0.57^{* \delta \delta \Phi}$ & $126 \pm 0.57^{* \delta \delta \Phi}$ & $52.23 \pm 0.33^{* \S \delta \Phi}$ & $228 \pm 1.53^{* \S \delta \Phi}$ & $118.7 \pm 1.45^{* \S \delta \Phi}$ \\
Group F & $363 \pm 0.57^{\S \delta \Phi \lambda}$ & $132 \pm 0.57^{* \S \delta \Phi \lambda}$ & $15 \pm 0.57^{* \delta \delta \Phi \lambda}$ & $303.3 \pm 1.201^{* \S \delta \Phi \lambda}$ & $132.7 \pm 0.88^{* \S \delta \Phi \lambda}$ \\
\hline
\end{tabular}

Values are mean \pm Standard Error of Mean (SEM) of data from the animals. *Implies significant difference when compared to Control (Group A); ${ }^{\S}$ Implies significant difference compared with Group B; ${ }^{\delta}$ Implies significant difference compared with Group C; ${ }^{\Phi}$ Implies significant difference compared with Group D; ${ }^{\lambda}$ Implies significant difference between Groups E and F. Significance was verified with ANOVA. SNK test was used for multiple comparisons. $\mathrm{P}<0.05 ; \mathrm{N}=6$. 
( $P>0.05) .800 \mathrm{mg} / \mathrm{kg}$ showed significantly high value when compared to groups $(\mathrm{P}>0.05)$. The quantity of acidophils in the pituitary gland in the secondary control group, as in 100, 200, 400 and $800 \mathrm{mg} / \mathrm{kg}$ body weight groups were significantly lower compared to primary control group $(\mathrm{P}<0.05)$. The quantity of basophils in the pituitary gland in 400 and $800 \mathrm{mg} / \mathrm{kg}$ body weight groups were significantly lower than the primary control $(\mathrm{P}<$ 0.05), while the secondary control, 100 and $200 \mathrm{mg} / \mathrm{kg}$ body weight groups showed high significant compared to the primary control group $(\mathrm{P}>0.05)$.

The quantity of granule cells of hypothalamus in the secondary control group and in all the treated groups were significantly higher compared to primary the control group $(\mathrm{P}>0.05)$. The value in the $100 \mathrm{mg} / \mathrm{kg}$ body weight group was significantly higher compared to secondary control group $(P>0.05)$, while 200, 400, and 800 $\mathrm{mg} / \mathrm{kg}$ body weight groups were significantly lower compared to corn oil group $(\mathrm{P}<0.05)$. The 400 and 800 $\mathrm{mg} / \mathrm{kg}$ group were significantly lower compared to other groups $(\mathrm{P}<0.05)$.

\subsection{Results of the Heamatoxylin and Eosin Staining (Figures 1-4)}
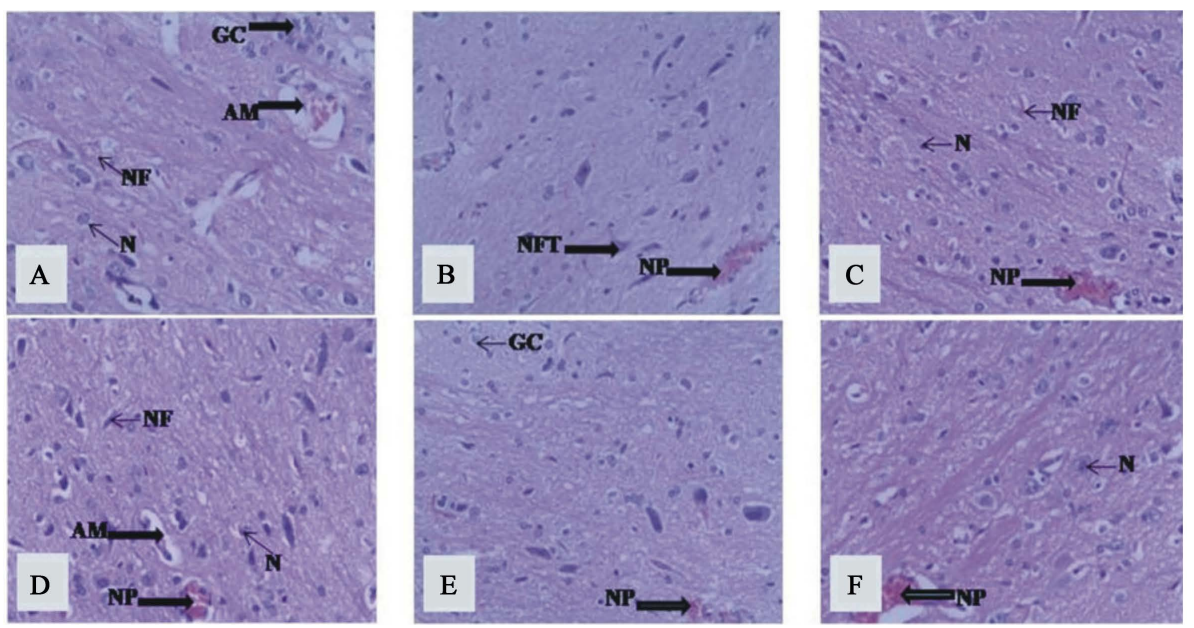

Figure 1. Photomicrograph of hypothalamus. (A) Primary control group; (B) Secondary control group; (C) 100 mg/kg; (D) $200 \mathrm{mg} / \mathrm{kg}$; (E) $400 \mathrm{mg} / \mathrm{kg}$; and (F) $800 \mathrm{mg} / \mathrm{kg}$ body weight. Observe normal neurons (N) that looks like the granule cells with distinct blue staining in primary control (A) and other groups (B, C, D, E, and F). Also seen are vacuolations around the neurons which are more prominent in the group $\mathrm{F}$ and less in the secondary control group B. Heamatoxylin and Eosin stain. $\times 400$.
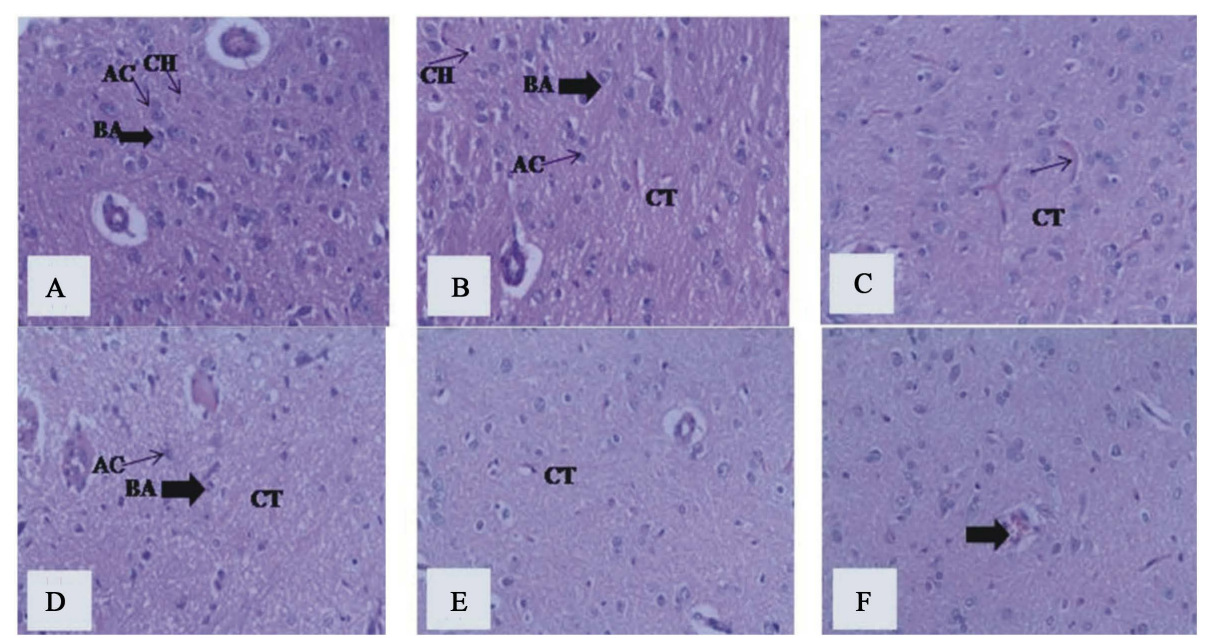

Figure 2. Photomicrograph of Pituitary. (A) Primary control group; (B) Secondary control group; (C) 100 mg/kg; (D) 200 $\mathrm{mg} / \mathrm{kg}$; (E) $400 \mathrm{mg} / \mathrm{kg}$; and (F) $800 \mathrm{mg} / \mathrm{kg}$ body weight. Primary control showed the presence of the basic pituitary cells. The acidophils (AC) and basophils (BA) are well stained, and conspicuous. Few chromophobes (CH) were seen. The connective tissue (CT) was intact. Notice a gradual decrease in the cells and connective tissues of pituitary across the treated groups (C, D, E, and F). Heamatoxylin and Eosin stain. $\times 400$. 

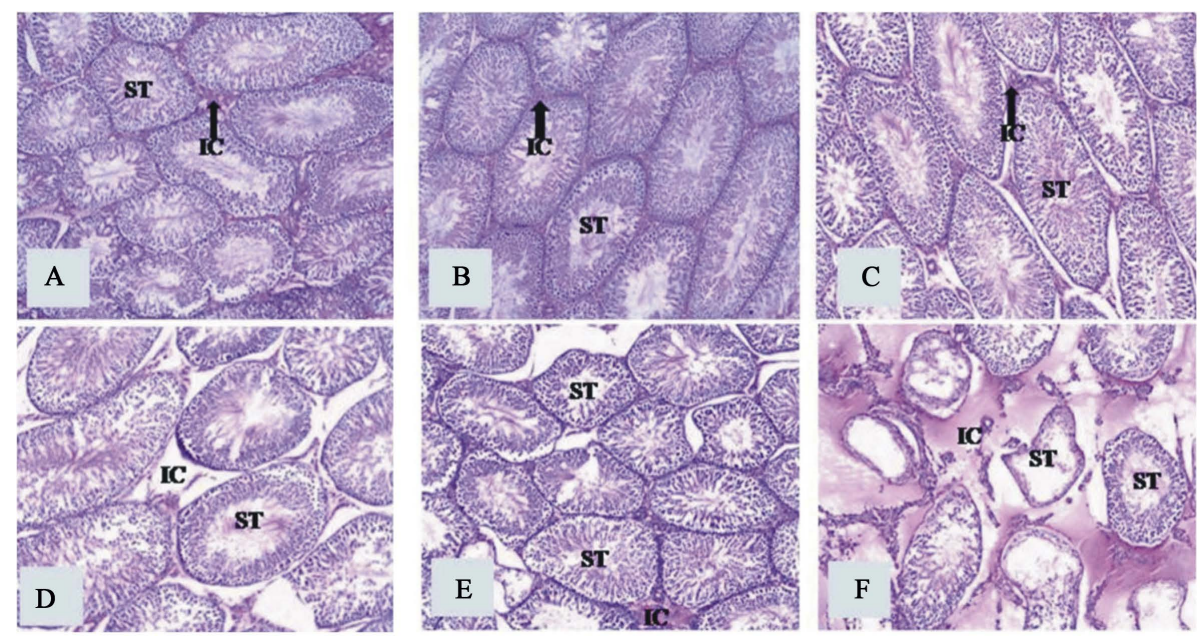

Figure 3. Photomicrograph of testes. (A) Primary or main control; (B) Secondary control; (C) 100 mg/kg; (D) 200 mg/kg; (E) $400 \mathrm{mg} / \mathrm{kg}$; and (F) $800 \mathrm{mg} / \mathrm{kg}$ body weight group. The primary control and corn oil groups showed normal histology of the testis. The alteration in the microanatomy was seen with the treated groups especially the $800 \mathrm{mg} / \mathrm{kg}$ per body weight group which showed dis-squamation and gross cellular depletion. Heamatoxylin and Eosin. $\times 100$.
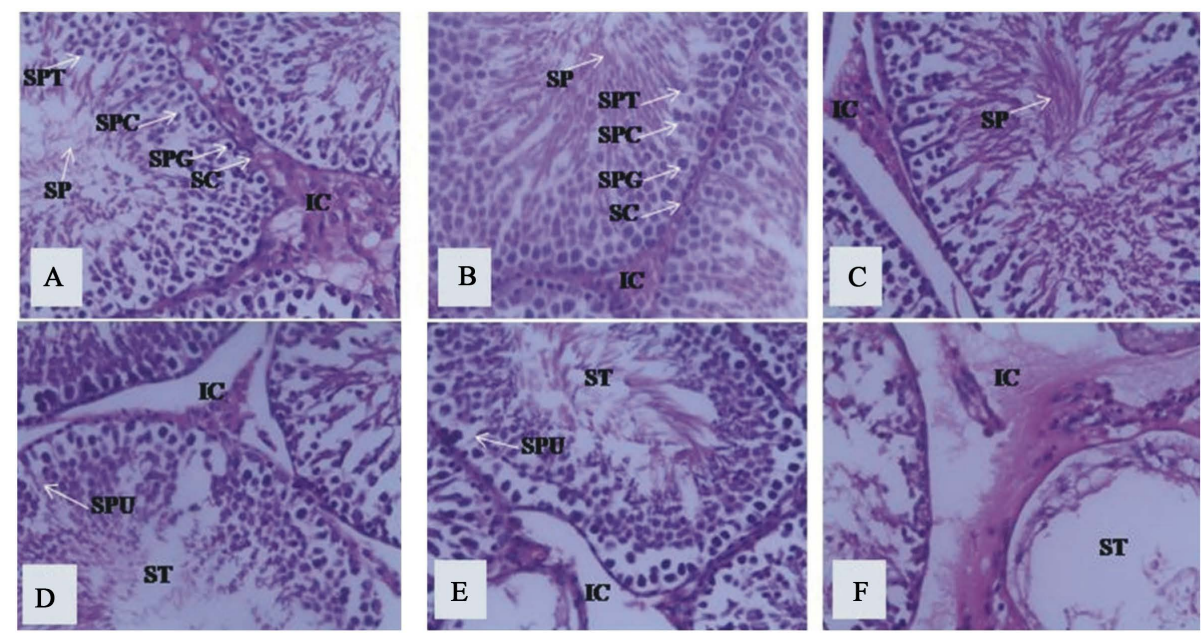

Figure 4. Photomicrograph of testes. (A) Primary or main control; (B) Secondary control; (C) 100 mg/kg; (D) 200 mg/kg; (E) $400 \mathrm{mg} / \mathrm{kg}$; and (F) $800 \mathrm{mg} / \mathrm{kg}$ body weight group. Control group (4A) showed normal architecture of the testes. Numerous siminiferous tubules (ST) which are held together by the supporting cells, called interstitial cells (IC) within which are found the leydig cells. The siminiferous tubules (ST) are lined by deferent types of cells which are supported by the sustentacular cells (SC). The deferent cell types include the spermatogonia cells (SPG), spermatocytes (SPC), spermatide (SPT) and finally the spermatozoa (SP) that filled the lumen of the tubules. Across the treated groups especially from groups D, E, and F noticed a gradual cellular depletion in the cells of the seminiferous tubules and the connective tissues. Heamatoxylin and Eosin. $\times 400$.

\section{Discussion}

Many beneficial effects of kolaviron, the bioflavonoid complex of G. kola have been reported [3] [9]-[12]. These effects have been attributed to its anti-inflammatory, antioxidant as well as its antigenotoxic abilities [13] [14]. Kolaviron has been demonstrated to be hepatoprotective against dimethyl nitosamnine-induced liver dam- age [13], tetra chloride-induced liver damage [15], and ethanol-induced oxidative stress in the liver [16]. Also kolaviron has been shown to be analgesic [17], antispasmodic and spasmolytic [18]. This complex of G. kola has also been implicated in neuroprotective role against gamma-radiation-induced brain injury [19], 3-nitro- propionic and methamphetamine-induced neurotoxicity [20] [21]. It has also been shown to posses hypoglycae- mic and hypolipidaemic effects in streptozotocin-induced diabetes [12]. Kolaviron has also been demonstrated to 
protect erythrocyte membranes from free radical attack on both lipids and proteins on the membrane [22].

In view of these many beneficial effects, G. Kola is widely consumed in many parts of Nigeria. Despite these numerous benefits, there are few reports of adverse following treatment with G. kola or this predominant constituent, kolaviron [23] [24].

The present study showed a general reduction in body weight gain of kolaviron treated groups compared to control. At $400 \mathrm{mg} / \mathrm{kg}$ body weight, kolaviron caused significant weight loss in group E animals. Retarded growth has been observed in rats feed with $G$. kola diet and this was attributed to intestinal mal-absorption and concomitant nutrient deficits induced as an endogenous effect of $G$. kola constituents [25]. These effects have also been shown following consumption of diets containing high levels of condensed tannins or flavonoid oligomers [25], and G. kola is known to possess considerable amounts of tannins [26], and flavoniods [1] and [27], with kolaviron, the flavonoid complex being the predominant constituent of G. kola. Also, it has been observed that chronic feeding on G. kola diet for as long as 6 weeks produced histological changes in duodenal villous epithelium likely to adversely affect the absorption of nutrients from the gut [25]. Decreased body weight gain following $G$. kola extract administration has been associated with reduced feed consumption, though this decrease has also been observed with accompanied decrease in food intake [23]. The present study showed kolaviron did not significantly affect testicular weight in treated animals. [23] Has also observed a similar result that $G$. kola extract did not alter testicular weight, though [28], observed a significant increase in testicular weight following administration of G. kola extract but with no accompanied effect on sperm count.

G. kola nut have been used as aphrodisiacs by the natives [29], and has been reported to posses sexual enhancing characteristics on male rats as evidenced by increased mounting, and intromission frequencies behaviours with increased number of subsequent ejaculations [28]. These behaviours have been indicated to be a measure of both libido and potency [28].

Studies on the effect of administration of G. kola or kolaviron only on microscopic anatomy of the brain and pituitary glands are scarce. Though Uko [23] no microscopic alterations in brains of rats were treated with extract of $G$. kola. In the present study, kolaviron was found to alter the histology of the hypothalamus, pituitary and testis of the male adult Wistar rats. The sections from the hypothalamus of rats administered with $400 \mathrm{mg} / \mathrm{kg}$ and $800 \mathrm{mg} / \mathrm{kg}$ per body of kolaviron showed hypertrophy of the neuronal fibres and atrophy of the granular cells. There was also an increase in the neurite plaque. Similar histological alterations were also observed with the sections of the pituitary of the male adult Wistar rats. The $400 \mathrm{mg} / \mathrm{kg}$ and $800 \mathrm{mg} / \mathrm{kg}$ per body weight of kolaviron also showed degeneration of the connective tissues and pituitary cells (acidophils and basophils) and other giant cells which were the secretory cell of the organ. Overall, there was little or not much effect of kolaviron in the brain (hypothalamus and pituitary), and this may probably be because of its neuroprotective effects as documented by Nwoha [20] [21]. However, the histology of the testes showed much more observable alterations than the pituitary and the hypothalamus. High dose of the kolaviron resulted in the degeneration of the cells in the tubules and the interstitial cells. [30] had earlier reported that prolonged administration of aqueous extract of G. kola resulted in degeneration of testicular cells in rabbit testes. Also [24] observed hypoplastic and degenerating semniferous tubules with disorganized epithelial cells in testes of dogs fed with G. kola extract. In contrast, [31] reported that treatment with G. kola extract showed improvement in structural integrity of the se- miniferous tubules, germinal epithelium and interstitial spaces in testes of rats following Lead II oxide induced- injury. [32] has reported that kolaviron improved marked degeneration of the testes observed following repro- ductive toxicity in sub-lethally whole body gamma-irradiated rats. [33] also reported that kolaviron improved severe testicular degeneration characterized by generation generalized erosion and necrosis of the germinal epi- thelium as well as reduction of Sertoli cells population in EGEE-induced reproductive toxicity. These effects again suggest that G. kola and/or kolaviron may improve reproductive health in cases of complications or dis- eases resulting in reproductive damage, but may not exhibit these beneficial effects when taken alone, especially for a prolonged duration and the abuse of the substance G. kola should be avoided irrespective of many benefi- cial effects.

\section{Conclusion}

In conclusion, this study has been able to show that kolaviron at $800 \mathrm{mg} / \mathrm{kg}$ body weight alters the microanatomy of the hypothalamus, pituitary and testes thereby affecting the hypothalamic-pituitary-gonadal axis. This histological alteration suggests that kolaviron at high dose may impair reproductive functions in the male adult 
Wistar rats.

\section{Acknowledgements}

The authors acknowledge the management of Institute Neuroscience and Biomedical Research (INBR) Owerri, for their valuable support and technical assistance.

\section{References}

[1] Farombi, E.O., Akanni, O.O. and Emerole, G.O. (2002) Antioxidative and Scavenging Activities of Kolaviron in Vitro. Pharmaceutical Biology, 40, 107-116. http://dx.doi.org/10.1076/phbi.40.2.107.5838

[2] Hodgson, J.M., Puddey, I.B., Croft, K.D., Burke, V., Mori, T.A. and Cacetta, R.A. (2000) Acute Effects of Ingestion of Black and Green Tea on Lipoprotein Oxidation. The American Journal of Clinical Nutrition, 71, 1103-1107.

[3] Akintowa, A. and Essien, A.R. (1990) Protective Effects of Garcinia kola Seed Extract against Paracetamol Induced Hepatotoxicity in Rats. Journal of Ethnopharmacology, 29, 207-211. http://dx.doi.org/10.1016/0378-8741(90)90057-Z

[4] Dhainaut, J.K., Thiji, L.G. and Park, G. (2000) Septic Shock. Saunders.

[5] Ayensu, E.S. (1978) Medicinal Plants of West Africa. Reference Publications, Algonac.

[6] Farombi, E.O., Adepoju, B.F., Ola-Davies, O.E. and Emerole, G.O. (2005) Chemoprevention of Aflatoxin B1-Induced Genotoxicity and Hepatic Oxidative Damage in Rats by Kolaviron, a Natural Biflavonoid of Garcinia kola Seeds. European Journal of Cancer Prevention, 14, 207-214. http://dx.doi.org/10.1097/00008469-200506000-00003

[7] Farombi, E.O. and Nwaokeafor, I.A. (2005) Anti-Oxidant Mechanism of Kolaviron; Studies on Serum Lipoprotein Oxidation, Metal Chelation and Oxidative Membrane Damage in Rats. Clinical and Experimental Pharmacology and Physiology, 32, 667-674

[8] Drury, R.A. and Wallington, E.A. (1980) Carleton’s Histological Techniques. 5th Edition, Oxford University Press, New York, 195.

[9] Iwu, M.M., Igboko, O.A., Okunji, C.O. and Tempesta, M.S. (1990) Anti-Diabetic and Aldose Reductase Activities of Biflavanones of Garcinia kola. Journal of Pharmacy and Pharmacology, 42, 290-292. http://dx.doi.org/10.1111/j.2042-7158.1990.tb05412.x

[10] Farombi, E.O., Tahnteng, J.G., Agboola, A.O., Nwankwo, J.O. and Emerole, G.O. (2000) Chemoprevention of 2- Acetylaminofluorene Induced Hepatotoxicity and Lipid Peroxidation in Rats by Kolaviron a Garcinia kola Seed Ex- tract. Food and Chemical Toxicology, 38, 535-541. http://dx.doi.org/10.1016/S0278-6915(00)00039-9

[11] Farombi, E.O., Adepoju, B.F., Ola-Davies, O.E. and Emerole, G.O. (2001) Inhibition of Aflatoxin B1-Induced Clastogenicity and Hepatocarcinogenicity by Kolaviron (Garcinia Biflavanones) in Rats. Mutation Research, 2001 483, S106.

[12] Adaramoye, O.A. and Adeyemi, E.O. (2006) Hypoglycaemic and Hypolipidaemic Effects of Fractions from Kolaviron, a Biflavonoid Complex from Garcinia kola in Streptozotocin-Induced Diabetes Mellitus Rats. Journal of Pharmacy and Pharmacology, 8, 121-128. http://dx.doi.org/10.1211/jpp.58.1.0015

[13] Farombi. E.O., Shrotriya, S. and Surh, Y. (2009) Kolaviron Inhibits Dimethyl Nitrosamine-Induced Liver Injury by Suppressing Cox-2 and Inos Expression via nf- $k \mathrm{~b}$ and ap-1. Life Sciences, 84, 149-155. http://dx.doi.org/10.1016/j.lfs.2008.11.012

[14] Farombi, E.O., Adedara, I.A., Ajayi, B.O., Ayepola, O.R. and Egbeme, E.E. (2013) Kolaviron, a Natural Antioxidant and Anti-Inflammatory Phytochemical Prevents Dextran Sulphate Sodium-Induced Colitis in Rats. Basic \& Clinical Pharmacology \& Toxicology, 113, 49-55. http://dx.doi.org/10.1111/bcpt.12050

[15] Adaramoye, O.A., Farombi, E.O., Nssien, M., Idowu, S.O., Ademowo, O.G. and Adeyemi, E.O. (2008) Hepatoprotective Activity of Purified Fractions from Garcinia kola Seeds in Mice Intoxicated with Carbon Tetrachloride. Journal of Medicinal Food, 11, 544-550.

[16] Adaramoye, O.A., Awogbindin, I. and Okusaga, J.O. (2009) Effect of Kolaviron, a Biflavonoid Complex from Garcinia kola Seeds on Ethanol-Induced Oxidative Stress in Liver of Adult Wistar Rats. Journal of Medicinal Food, 12, 584-590. http://dx.doi.org/10.1089/jmf.2008.0138

[17] Olaleye, S.B., Farombi, E.O., Adewoye, E.A., Owoyele, B.V., Onasanwo, S.A. and Elegbe, R.A. (2000) Analgesic and Anti-Inflammatory Effects of Kolaviron (a Garcinia kola Seed Extract). African Journal of Biomedical Research, 3, 171-174.

[18] Udia, P.M., Braide, V.B. and Owu, D.U. (2009) Antispasmodic and Spasmolytic Effects of Methanolic Extract from Seeds of Garcinia kola on Isolated Rat Small Intestine. Nigerian Journal of Physiological Sciences, 24, 111-116

[19] Adaramoye, O.A. (2010) Protective Effect of Kolaviron, a Biflavonoid from Garcinia kola Seeds, in Brain of Wistar Albino Rats Exposed to Gamma-Radiation. Biological \& Pharmaceutical Bulletin, 33, 260-266. 
http://dx.doi.org/10.1248/bpb.33.260

[20] Nwoha, P.U., Ojo, B., Ajayi, S.A., Ofusori, D.A., Oluwayinka, O.P., Odukoya, S.A. and Falana, B.A. (2007) Garcinia kola Diet Provides Slight Protection to Mice Hippocampal Neurons against Neuro-Toxins. J. Environ Neurosci. Biomed, 1, 125-136.

[21] Ijomone, O.M., Nwoha, P.U., Olaibi, O.K., Obi, A.U. and Alese, M.O. (2012) Neuroprotective Effects of Kolaviron, a Biflavonoid Complex of Garcinia kola, on Rats Hippocampus against Methamphetamine-Induced Neurotoxicity. Macedonian Journal of Medical Sciences, 5, 10-16. http://dx.doi.org/10.3889/MJMS.1857-5773.2011.0203

[22] Adaramoye, O.A. and Akinloye, O. (2000) Possible Protective Effect of Kolaviron on CCl4-Induced Erythrocyte Damage in Rats. Bioscience Reports, 20, 259-264. http://dx.doi.org/10.1023/A:1026488823157

[23] Uko, O.J., Usman, A. and Ataja, A.M. (2001) Some Biological Activities of Garcinia kola in Growing Rats. Veterinary Archives, 71, 287-297.

[24] Notridge, H.O., Omobowale, T.O., Taiwo, V.O. and Omotoso, M.A. (2008) Histopathological Studies on the Effects of Ethanolic Extract of the Fruits of Garcinia kola on Selected Organs of the Dogs. International Journal of Morphology, 26, 1069-1072.

[25] Braide, V.B. (1990) Pharmacological Effects of Chronic Ingestion of Garcinia kola Seeds in the Rat. Phytotherapy Research, 4, 39-41. http://dx.doi.org/10.1002/ptr.2650040110

[26] Adegboye, M.F., Akinpelu, D.A. and Okoh, A.I. (2008) The Bioactive and Phytochemical Properties of Garcinia kola (Heckel) Seed Extract on Some Pathogens. African Journal of Biotechnology, 7, 3934-3938.

[27] Adaramoye, O.A., Farombi, E.O., Adeyemi, E.O. and Emerole, G.O. (2005) Inhibition of Human Low Density Lipoprotein Oxidation by Flavonoids of Garcinia kola Seeds. Pakistan Journal of Medical Sciences, 21, 331-339.

[28] Ralebona, N., Sewani-Rusike, C.R. and Nkeh-Chungag, B.N. (2012) Effects of Ethanolic Extract of Garcinia kola on Sexual Behaviour and Sperm Parameters in Male Wistar Rats. African Journal of Pharmacy and Pharmacology, 6, 1077-1082. http://dx.doi.org/10.5897/AJPP11.652

[29] Iwu, M.M. (1993) Handbook of African Medicinal Plants. CRC Press, London, 183-184.

[30] Akinloye, A.K., Igbarha, O.O., Olaniyi, M.O., Alaka, O.O. and Oke, B.O. (2000) Preliminary Investigation on the Effects of Bitter Kola Extract on Rabbit Testes and Epididymides. Tropical Veterinarian, 18, 49-54.

[31] Dare, B.J., Chukwu, R.O., Oyewopo, A.O., Makanjuola, V.O., Olayinka, P.O., Akinrinade, I.D., Olaniyan, T.O., Omotoso, O.D., Shafe, M.O., Ogundele, O.M., Beremako, O.O. and Adeh, M.N. (2012) Histological Integrity of the Testis of Adult Wistar Rats (Rattus Novergicus) Treated with Garcinia kola. Reproductive System \& Sexual Disorders, 1, 4.

[32] Adaramoye, O.A., Adedara, I.A. and Farombi, E.O. (2012) Posible Ameliorative Effects of Kolaviron against Reproductive Toxicity in Sub-Lethally Whole Body Irradiated Rats. Experimental and Toxicological Pathology, 64, $379-385$. http://dx.doi.org/10.1016/j.etp.2010.10.002

[33] Adedara, I.A. and Farombi, E.O. (2012) Chemoprotection of Ethylene Glycol Monoethyl Ether-Induced Reproductive Toxicity in Male Rats by Kolaviron, Isolated Biflavonoid from Garcinia kola Seed. Human \& Experimental Toxicology, 31, 506-517. http://dx.doi.org/10.1177/0960327111424301 
Scientific Research Publishing (SCIRP) is one of the largest Open Access journal publishers. It is currently publishing more than 200 open access, online, peer-reviewed journals covering a wide range of academic disciplines. SCIRP serves the worldwide academic communities and contributes to the progress and application of science with its publication.

Other selected journals from SCIRP are listed as below. Submit your manuscript to us via either submit@scirp.org or Online Submission Portal.
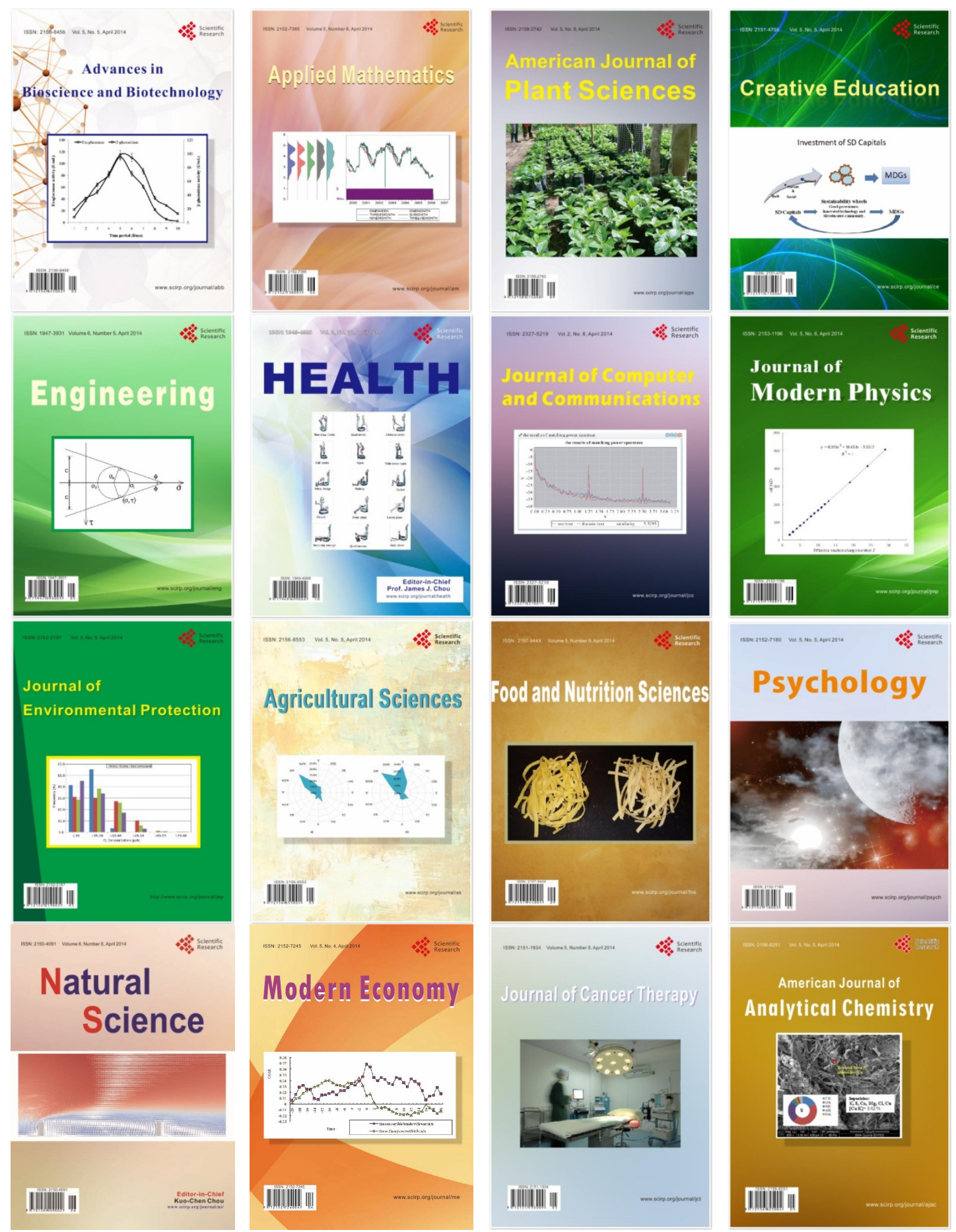